\title{
FAKTOR-FAKTOR YANG BERHUBUNGAN DENGAN KEJADIAN DEMAM BERDARAH DENGUE (DBD) DI DESA PANJI KECAMATAN SUKASADA KABUPATEN BULELENG
}

\author{
Gede Wahyu Kurniasa ${ }^{1}$, I Wayan Suarta Asmara
}

\begin{abstract}
The number of dengue cases in Buleleng Regency has increased in 2019 from IR 19,6 to 249,5 per 100.000 population. In the last 5 years, Puskesmas Sukasada I has always been in the top 3 position. The village of Panji experienced an increase in dengue cases from 0 to 50 cases in 2019. The purpose of this study was to determine the factors related to the incidence of dengue in Panji Village, Sukasada District, Buleleng Regency. The study design using the case control approach was carried out in May 2020. Data used from the results of interviews and observations. From the results of statistical tests with Chi Square from 88 respondents it can be concluded about factors that are significantly related to the incidence of DHF including the presence of Aedes aegypti mosquito larvae, the habit of using anti-mosquito repellent, eradication of mosquito nests with $3 M$ plus and the habit of hanging clothes with a value of $p<0,05$. Respondents' knowledge about DHF is not significantly related to the incidence of DHF. Community participation and cross-sectoral cooperation are needed in the implementation of the DHF PSN to create a larva free village as a way to prevent the transmission of DHF.
\end{abstract}

Keywords : Environment, Host, DHF events.

\section{PENDAHULUAN}

Penyakit berbasis lingkungan merupakan fenomena penyakit yang terjadi pada sebuah kelompok masyarakat, yang berhubungan, berakar, atau memiliki keterkaitan erat dengan satu atau lebih komponen lingkungan pada sebuah ruang dimana masyarakat tersebut tinggal atau beraktifitas dalam jangka waktu tertentu. (1). Penyakit DBD dapat muncul sepanjang tahun dan dapat menyerang seluruh kelompok umur. Di Indonesia pertama kali dilaporkan terjadi di Surabaya dan Jakarta pada tahun 1968, tiap tahun kasus penyakit ini meningkat dan menyebar ke seluruh pelosok tanah air. Angka kejadian kasus DBD di Indonesia dari tahun ke tahun cenderung fluktuatif. Wilayah yang paling tinggi angka kesakitannya adalah Pulau Jawa, NTB, Bali, Papua, Maluku Utara, dan sebagian Sumatra dengan insiden < 49/100.000 penduduk. (2).

Kejadian kasus DBD di kabupaten Buleleng di tahun 2019 
cenderung mengalami peningkatan cukup tajam dari angka kesakitan DBD 19,6 per 100.000 penduduk di tahun 2018 menjadi 249,5 per 100.000 penduduk di tahun 2019. Sebaran kasus DBD per puskesmas di Kabupaten Buleleng dalam 5 tahun terakhir, Puskesmas Sukasada I selalu berada pada posisi 3 besar terbanyak. Desa Panji yang mengalami peningkatan jumlah kasus DBD dari 0 kasus di tahun 2017 sampai menjadi 50 kasus di tahun 2019. (3). Meningkatnya jumlah kasus DBD dapat disebabkan mobilitas penduduk, adanya pemukiman baru, kepadatan penduduk, penyuluhan dan perilaku masyarakat. semakin padat densitasnya larva Aedes aegypti memiliki hubungan meningkat kejadian penyakit DBD.

Tujuan penelitian untuk mengetahui faktor-faktor yang berhubungan dengan penyakit DBD seperti keberadaan jentik nyamuk Aedes aegypti , pengetahuan responden tentang penyakit DBD, kebiasaan memakai obat anti nyamuk, pemberantasan sarang nyamuk dengan $3 \mathrm{M}$ plus, kebiasaan menggantung pakaian dan menganalisis faktor-faktor yang mempengaruhi kejadian penyakit DBD di Desa Panji Kecamatan Sukasada Kabupaten Buleleng.

\section{METODE PENELITIAN}

Rancangan penelitian menggunakan metode survei analitik dengan pendekatan case control yaitu mempelajari faktor-faktor yang berhubungan kejadian penyakit DBD, dengan cara membandingkan kelompok kasus dan kelompok kontrol. (4). Populasi penderita DBD tahun 2019 sebanyak 50 orang sehingga sampel berjumlah 44 orang, sampel diambil dari penderita DBD tahun 2019 dan yang tidak menderita DBD sebagai kontrol berjumlah 44 orang. Teknik pengumpulan data dengan wawancara, observasi dan dokumentasi yang dilaksanakan Mei 2020. Pada penelitian ini menggunakan uji analitik Chi Square dengan kemaknaan $p \leq 0,05$ dan untuk mengetahui besar faktor resiko digunakan analisis Odd Ratio (OR). (5). 
HASIL DAN PEMBAHASAN

Keberadaan jentik nyamuk Aedes aegypti

Dari hasil penelitian keberadaan jentik nyamuk Aedes aegypti pada rumah responden pada kelompok kontrol sebesar 29,5\% lebih kecil bila dibandingkan dengan kelompok kasus 70,5\% sedangkan tidak ada keberadaan jentik nyamuk Aedes aegypti pada rumah responden pada kelompok kontrol sebesar 75\% lebih besar apabila dibandingkan dengan kelompok kasus $25 \%$.

Hasil analisis statistik dengan menggunakan uji Chi Square menunjukkan nilai $p=0,000(p<$ $0,05)$ dan nilai $\mathrm{OR}=7,154(95 \% \mathrm{CI}$ $=2,792-18,328)$. Berdasarkan hasil tersebut diketahui ada hubungan yang bermakna antara keberadaan jentik nyamuk Aedes aegypti dengan kejadian DBD. Dari nilai OR berarti bahwa ada keberadaan jentik nyamuk Aedes aegypti pada rumah responden berisiko 7,15 kali lebih besar menderita DBD.

Tempat yang kurang bersih dan airnya jernih serta terlindung dari sinar matahari langsung merupakan tempat perkembangbiakan nyamuk Aedes aegypti. Tempat yang disukai sebagai tempat berkembangbiaknya adalah tempat air yang lokasinya di dalam dan dekat rumah. (6).

Upaya yang dapat dilakukan dengan pemeriksaan jentik berkala (PJB), program ini bertujuan untuk melakukan pemeriksaan jentik nyamuk penular DBD dan memotivasi keluarga atau masyarakat dalam melakukan pemberantasan sarang nyamuk (PSN) DBD. Program PJB dapat dilakukan oleh kader, PKK, jumantik atau tenaga pemeriksa jentik lainnya. (7).

Hasil penelitian ini sejalan dengan penelitian I Gusti Putu Anom Surya dkk, (2012) menyatakan ada hubungan densitas jentik/ larva Aedes aegypti dengan kejadian DBD, semakin padat densitasnya larva Aedes aegypti memiliki hubungan meningkat kejadian penyakit DBD dengan nilai $p=0,00(p<0,05)$. (8). Hal senada juga dari penelitian Pramudiyo Teguh Sucipto, dkk (2015) menyatakan ada hubungan yang signifikan antara tempat penampungan air yang terdapat jentik dengan kejadian DBD dengan nilai $p=0,001$ nilai $\mathrm{OR}=8,8(95 \%$ $\mathrm{CI}=3,615-21,423)$. Dengan 
responden yang mempunyai tempat penampungan air yang berjentik mempunyai risiko 8,8 kali lebih besar dari pada responden yang tempat penampungan airnya tidak terdapat jentik menderita DBD. (9).

\section{Pengetahuan responden tentang penyakit DBD}

Dari hasil penelitian pengetahuan responden tentang penyakit DBD kategori kurang pada kelompok kontrol sebesar 31,8\% lebih kecil bila dibandingkan dengan kelompok kasus 45,5\% sedangkan yang memiliki pengetahuan tentang penyakit DBD kategori baik pada kelompok kontrol sebesar 68,2\% lebih besar apabila dibandingkan dengan kelompok kasus $54,5 \%$.

Hasil analisis statistik dengan menggunakan uji Chi Square menunjukkan nilai $p=0,189(p>$ $0,005)$ dan nilai $\mathrm{OR}=1,786(95 \% \mathrm{CI}$ $=0,749-4,257)$. Berdasarkan hasil tersebut diketahui tidak ada hubungan yang bermakna antara pengetahuan responden tentang penyakit DBD dengan kejadian DBD. Dari nilai OR berarti bahwa responden yang memiliki pengetahuan kurang tentang penyakit
DBD mempunyai risiko 1,79 kali lebih besar menderita DBD

Penelitian ini tidak sejalan dengan hasil penelitian I Made Dwie Pradnya Susila (2016) yang menyatakan ada hubungan yang signifikan antara tingkat pengetahuan DBD dengan kejadian DBD dengan nilai $p=0,036(p<0,05)$. (10). Hal senada juga dari Vega Inge Umboh, dkk (2016) dengan analisis statistik dengan uji Chi Square menunjukkan nilai $p=0,004(p<0,05)$ dan nilai $\mathrm{OR}=5,571(95 \%$ CI $1,804-17,203)$ menyatakan bahwa responden yang memiliki pengetahuan yang kurang berisiko 5,571 kali menderita DBD dibandingkan dengan responden yang memiliki pengetahuan yang baik. (11)

Meningkatkan kesadaran masyarakat dimulai dari peningkatan pengetahuan masyarakat, namun terkadang masyarakat baru beraksi bila dipaksa, dan diharapkan gerakan-gerakan tersebut membuat masyarakat memahami pentingnya menjaga kesehatan. Dengan gerakangerakan tersebut sebagai pembudayaan PSN 3M Plus secara berkelanjutan sepanjang tahun dan 
guna mewujudkan terlaksananya Gerakan 1 Rumah 1 Jumantik.

\section{Kebiasaan memakai obat anti nyamuk}

Dari hasil penelitian bahwa responden yang memiliki kebiasaan memakai obat anti nyamuk kategori baik pada kelompok kontrol sebesar $68,2 \%$ lebih besar bila dibandingkan dengan kelompok kasus 31,8\%, sedangkan responden yang memiliki kebiasaan memakai obat anti nyamuk kategori kurang pada kelompok kontrol sebesar $31,8 \%$ lebih kecil bila dibandingkan dengan kelompok kasus 68,2\%.

Hasil analisis statistik dengan menggunakan uji Chi Square menunjukkan nilai $p=0,001(p<$ $0,05)$ dan nilai $\mathrm{OR}=4,592(95 \% \mathrm{CI}$ $=1,872-11,262)$. Berdasarkan hasil tersebut ada hubungan yang bermakna antara kebiasaan memakai obat anti nyamuk dengan kejadian DBD. Dari nilai OR bahwa responden yang memiliki kebiasaan memakai obat anti nyamuk kategori kurang mempunyai risiko 4,59 kali lebih besar menderita DBD.

Penelitian ini sejalan dengan penelitian Pramudiyo Teguh Sucipto dkk (2015), menyatakan bahwa ada $\begin{array}{llr}\text { hubungan } & \text { antara kebiasaan } \\ \text { menggantung } & \text { pakaian dengan }\end{array}$ kejadian DBD, dengan nilai $p=$ 0,036 dan $\mathrm{OR}=5,4$ yang artinya kebiasaan tidak memakai anti nyamuk/repellent mempunyai risiko 5,4 kali lebih besar dari pada kebiasaan memakai anti nyamuk/repellent menderita DBD. (9). Hal senada juga dari penelitian Tuti Sandra dkk, (2018) menyatakan anak yang tidak memiliki kebiasaan memakai obat anti nyamuk merupakan mempunyai risiko 4 kali lebih besar untuk menderita DBD dibandingkan anak yang memiliki kebiasaan memakai obat anti nyamuk. (12).

\section{Pemberantasan sarang nyamuk dengan $3 \mathrm{M}$ plus}

Dari hasil penelitian bahwa responden yang memiliki kebiasaan memakai obat anti nyamuk kategori baik pada kelompok kontrol sebesar $68,2 \%$ lebih besar apabila dibandingkan dengan kelompok kasus 31,8\% sedangkan responden yang memiliki kebiasaan memakai obat anti nyamuk kategori kurang pada kelompok kontrol sebesar $31,8 \%$ lebih kecil bila dibandingkan dengan kelompok kasus 68,2\%. 
Hasil analisis statistik dengan menggunakan uji Chi Square menunjukkan nilai $p=0,000(p<$ $0,05)$ dan nilai $\mathrm{OR}=5,800(95 \% \mathrm{CI}$ $=2,302-14,616)$. Berdasarkan hasil tersebut ada hubungan antara pemberantasan sarang nyamuk dengan 3M plus dengan kejadian DBD. Dari nilai OR berarti risiko 5,8 kali lebih besar bagi responden yang kurang melakukan pemberantasan sarang nyamuk dengan $3 \mathrm{M}$ plus menderita DBD.

Kemauan dan tingkat kedisiplinan PSN dengan 3M plus di masyarakat perlu ditingkatkan. Praktik ini dapat dimulai dari lingkungan tempat tinggal. Gerakan PSN adalah keseluruhan kegiatan yang dilakukan oleh seluruh lapisan masyarakat dan pemerintah untuk mencegah penyakit DBD yang disertai pemantauan hasil-hasilnya secara terus menerus. Gerakan PSN DBD merupakan bagian terpenting dari kesehatan upaya pemberantasan penyakit DBD. (13).

Penelitian ini sejalan dengan penelitian Tuti Sandra dkk, (2018) menyatakan ada pegaruh faktor praktik PSN yang kurang baik terhadap kejadian DBD pada anak usia 6-12 tahun. Dari hasil uji statistik dengan nilai $p=0,025$ dan $\mathrm{OR}=2,471(95 \% \mathrm{CI}=1,108-$ 5,978). Hal ini berarti responden yang kurang baik dalam praktik PSN mempunyai kemungkinan 2,5 kali untuk mengalami kejadian DBD. (12).

\section{Kebiasaan menggantung pakaian}

Dari hasil penelitian bahwa responden yang tidak biasa menggantung pakaian pada kelompok kontrol sebesar 70,5\% lebih besar apabila dibandingkan dengan kelompok kasus 22,7\%, sedangkan responden yang memiliki kebiasaan menggantung pakaian pada kelompok kontrol sebesar 29,5\% lebih kecil bila dibandingkan dengan kelompok kasus 77,3\%.

Hasil analisis statistik dengan menggunakan uji Chi Square menunjukkan nilai $p=0,000(p<$ $0,05)$ dan nilai $\mathrm{OR}=8,108(95 \% \mathrm{CI}$ $=3,113-21,119)$. Berdasarkan hasil tersebut ada hubungan kebiasaan menggantung pakaian dengan kejadian DBD. Dari nilai OR berarti risiko 8,11 kali lebih besar bagi responden yang memiliki kebiasaan menggantung pakaian menderita DBD. 
Menurut teori, nyamuk Aedes aegypti mempunyai kebiasaan istirahat terutama di dalam rumah di tempat yang gelap, lembap pada benda-benda yang bergantung seperti tirai atau pakaian yang menggantung pada dinding/ ruangan. (6). Kegiatan PSN dan 3M ditambahkan dengan cara menghindari kebiasaan menggan-tung pakaian di dalam kamar merupakan kegiatan yang mesti dilakukan untuk mengendalikan populasi nyamuk Aedes aegypti, sehingga penularan penyakit DBD dapat dicegah.

Penelitian ini sejalan dengan penelitian Pramudiyo Teguh Sucipto dkk, (2015) menyatakan bahwa ada hubungan antara kebiasaan menggantung pakaian dengan kejadian DBD, dengan nilai $p=0,001$ dan nilai $\mathrm{OR}=3,9(95 \%$ CI $1,108-$ 9,861). Hal ini berarti risiko 3,9 kali lebih besar daripada yang tidak mempunyai kebiasaan menggantung pakaian untuk terjadi-nya penyakit DBD. (9).

\section{SIMPULAN}

Berdasarkan hasil pembahasan penelitian dapat disimpulkan sebagai berikut:

1. Ada hubungan antara keberadaan jentik nyamuk Aedes aegypti dengan kejadian DBD dengan nilai $p=0,000$ dan nilai $\mathrm{OR}=$ $7,154(95 \% \mathrm{CI}=2,792-18,328)$.

2. Tidak ada hubungan pengetahuan responden tentang penyakit DBD dengan kejadian DBD pengetahuan responden tentang DBD dengan kejadian DBD dengan nilai $p=0,189$ dan nilai $\mathrm{OR}=1,786(95 \% \mathrm{CI}=0,749-$ 4,257).

3. Ada hubungan antara kebiasaan memakai obat anti nyamuk dengan kejadian DBD dengan nilai $\quad p=0,001$ dan nilai $\mathrm{OR}=$ $4,592(95 \%$ CI $=01,872-$ 11,262).

4. Ada hubungan pemberantasan sarang nyamuk dengan $3 \mathrm{M}$ plus dengan nilai $p=0,000$ dan nilai $\mathrm{OR}=5,800(95 \% \mathrm{CI}=2,302-$ 14,616).

5. Ada hubungan antara kebiasaan menggantung pakaian dengan kejadian DBD dengan nilai $p=$ 
0,000 dan nilai $\mathrm{OR}=8,108(95 \%$

$\mathrm{CI}=3,113-21,119)$.

6. Faktor-faktor yang berhubungan kejadian penyakit DBD di Desa Panji Kecamatan Sukasada Kabupaten Buleleng diantaranya keberadaan jentik nyamuk Aedes aegypti, kebiasaan memakai obat anti nyamuk, pemberantasan sarang nyamuk dengan $3 \mathrm{M}$ plus dan kebiasaan menggantung pakaian.

\section{SARAN}

1. Bagi masyarakat untuk lebih berperan serta dalam kegiatan PSN 3M plus secara mandiri dan teratur.

2. Bagi instansi Puskesmas Sukasada I dan Dinas Kesehatan Kabupaten Buleleng agar melaksanakan kerjasama lintas sektoral dalam hal ini pemerintah Desa Panji maupun Kecamatan Sukasada dengan membuat gerakan serentak PSN DBD 3 bulan sekali berupa pemeriksaan jentik berkala (PJB) dan gerakan jumat bersih guna wujudkan desa/kelurahan bebas jentik dan terlaksananya Gerakan 1 Rumah 1 Jumantik.

\section{DAFTAR PUSTAKA}

1. Achmadi UF. Dasar-Dasar Penyakit Berbasis Lingkungan. Jakarta: Rajawali Pers; 2012. 1$184 \mathrm{p}$.

2. Kemenkes RI. Profil Kesehatan Indonesia 2018 [Indonesia Health Profile 2018] [Internet]. 2019. 1-207 p. Available from: http://www.depkes.go.id/resourc es/download/pusdatin/profilkesehatan-indonesia/Data-danInformasi_Profil-KesehatanIndonesia-2018.pdf

3. Dinas Kesehatan Kabupaten Buleleng. Profil Kesehatan Kabupaten Buleleng 2020. Dinas Kesehat Kabupaten Buleleng. 2020;1-53.

4. Sastroasmoro S. Dasar-Dasar Metodologi Penelitian Klinis. Jakarta: CV. Sagung Seto; 2002. 1-522 p.

5. Sugiyono. Statistika Untuk Penelitian. Cetakan ke. Bandung: Alfabeta; 2014. 1-402 p.

6. Soegijanto S. Demam Berdarah Dengue. Edisi 2. Surabaya: Airlangga University Press; 2006. 272 p.

7. Depkes RI. Pencegahan dan 
Pemberantasan Demam

Berdarah di Indonesia. Dirjen P2 \& PL, editor. Jakarta: Depkes RI; 2005. 1-80 p.

8. Surya IGPA, Aryana IK, Jana IW. Faktor-faktor yang berhubungan dengan kejadian DBD di Kelurahan Abianbase kecamatan Mengwi Kabupaten Badung. 2012;181-185.

9. Pramudiyo Teguh Sucipto, Raharjo M, Nurjazuli. Dynamical degrees of (pseudo)automorphisms fixing cubic hypersurfaces. J Kesehat Lingkung Indones. 2015;14(2):51-56.

10. Susila IMDP. Hubungan Tingkat Pengetahuan DBD dengan Kejadian DBD di Banjar Pegok, Desa Sesetan, Kecamatan Denpasar Selatan. J Dunia Kesehat [Internet]. 2014;5(1):28-33. Available from:

https://media.neliti.com/media/p ublications/76494-ID-hubungantingkat-pengetahuan-dbddengan.pdf

11. Umboh VI, Kandou GD, Kepel
BJ. Hubungan antara Pengetahuan dan SIkap tentang Program 3M plus dengan Kejadian DBD di Wilayah Kerja Puskesmas Ranotana Weru Kota Manado. J Ikmas. 2016;8(3):19.

12. Sandra T, Muchlis AU Sofro, Suhartono, Martini, Hadisaputro S. Faktor Yang Berpengaruh Terhadap Kejadian Demam Berdarah Various Factors Influencing the Dengue Fever Occurrences in the Children Age 6 To 12 Years Old. J Ilm Permas. 2019;9(1):28-35.

13. Kementrian Kesehatan Republik Indonesia. Modul Pengendalian Demam Berdarah Dengue [Internet]. Direktur Jenderal PP dan PL, editor. Vol. 7, Kesmas: National Public Health Journal. Jakarta: Kementrian Kesehatan Republik Indonesia; 2011. 1120 p. Available from: https://www.academia.edu/3224 7292/Manajemen_DBD_all 